\section{Dr. E. P. Poulton}

Edward Palmer Poulton, who died on October 18, was the eldest son of Sir Edward Poulton. $\mathrm{He}$ was born at Oxford in 1883, and educated at the Dragon School, Oxford, and at Rugby; in 1902 he obtained the Brackenbury Scholarship in natural science at Balliol College, Oxford. After taking the First M.B. he read Chemistry Finals.

Poulton went to Guy's Hospital for his clinical work in 1907 and qualified B.M. (Oxon.) in 1910. After appointment as house physician, he won the Radcliffe Travelling Fellowship and worked in Germany. His early scientific work (1912-14) was mostly on the metabolism of uric acid and of creatin and creatinin.

In 1914 Poulton was appointed assistant physician to Guy's Hospital, and he becamo interested in the chemical side of diabetes, working on the value of alveolar air determinations as a measure of the acidosis and also writing on the value of starvation in the treatment of diabetes. The introduction of insulin in 1922 intensified his interest in diabetes, and his main clinical work continued to be with diabetic patients.

In 1920 he was elected to a Beit Memorial Research fellowship. At an early stage he had worked with Haldane on the effects of want of oxygen on respiration, and this influenced the direction of much of his later work. From 1918 until 1925, with a series of pupils, Debenham, Joffe, Campbell, Parsons, and later Spurrell and Warner, he was working continually on the problem of dyspnœa in connexion with the oxygen and carbon dioxide carriers in the blood, and with its hydrogen ion concentration and with the oxyhamoglobin curve. For a time at Guy's Hospital an oxygen chamber was installed whero patients could live in an atmosphere of, say, 40 per cent oxygen, and the influence of this on their disease and on their physiological processes could be observed. He was satisfied that many patients with chronic bronchitis and heart disease obtained benefit from this treatment, and this was the foundation of his belief in oxygen therapy which became the main interest of his later years.

Another early interest to which Poulton returned again was the problems of pain in gastric ulcer and of pain and of normal sensation in the œsophagus. $\mathrm{He}$ carried out investigations on himself and others by introducing into the œsophagus a balloon which could be distended while the subject was under $\mathrm{X}$-ray examination. In 1928 he gave the OliverSharpey Lectures, dealing with the experimental study of certain visceral sensations, and the next year published a paper in the Guy's Hospital Reports on the physiological considerations underlying ab. dominal pain.

The mechanical side of any investigation always made a great appeal to Poulton, and much of his later work was concerned with the development of apparatus, for example, positive pressure machines and oxygen tents. Although often rather complicated in appearance, his oxygen tent in its final form was a neat and beautiful piece of apparatus. His enthusiasm for oxygen therapy has no doubt been one of the factors leading to the increased use of this treatment; latterly his enthusiasm led him to start experimental observations on patients with such diverse conditions as rheumatic carditis and cerebral hæmorrhage.

Apart from the many published papers on the subjects mentioned, Poulton published two books, "Oxygen and Carbon Dioxido Therapy" with Argyll Campbell, and "Diets and Recipes and Treatment of Diabetes and Obesity". He also acted as editor of the 12th to 14th editions of "Taylor's Practice of Medicine", the first of these in 1922. This was perhaps his greatest contribution to medical teaching ; he devoted much time and trouble to the preparation of each edition, so that this old text-book was made a good practical guide and kept remarkably up to date.

Poulton was chairman of the International Society of Medical Hydrology, and in 1937 was president of Section I (Physiology) of the British Associationan unusual distinction for a practising physician. Ho was also greatly interested in the work of the League of Nations Union and spent much time on this.

There wero many qualities, ineluding his whole. hearted enthusiasm and his charm and kindliness, which endeared him to his many friends. Although ho know his heart was affected, his regular hospital duties and teaching, his research work and writing, and his many societies and meetings, show how littlo ho let this stand in the way, and in their multifarious activities he nover spared himself.

In 1911 Poulton had married Elfrida, youngest daughter of Mr. Charles Maclean of Glenearn, Perthshire, and had three sons and two daughters. His eldest son has recently qualified and is now a medical officer at Pembury, the second is in the Army, and the third a medical student.

M. Campbeli.

\section{Major A. E. Levin}

WE regret to announce the death of Major Arthur Everard Lovin, which took place on November 8 after a short illness. Levin was born on February 17, 1872, and was educated privately. He took up electrical engineering as a profession and enlisted in the Royal Engineers on the outbreak of the South African War. For some time after the conclusion of that war he held a Government appointment and later was associated with the firm of Mordey and Dawbarn, consulting electrical engineers, retiring from his profession in 1928. Ho remained with the old 'Volunteers' when they became 'Territorials' and was called up for service on August 5, 1914. Later he was placed in command of the first Electrical and Mechanical Company to be sent to France, and was mentioned in dispatches in April 1918. Ho saw servico in Italy in the same year.

After demobilization, Levin's interests turned to astronomy. In 1919 he was elected a member of the British Astronomical Association and in 1921 a fellow of the Royal Astronomical Society. His work in astronomy was mainly connected with computations. 